\title{
Restrukturisasi Kredit Sektor Porperti dan Real Estate
}

\author{
Muryati Marzuki
}

\begin{abstract}
The discussion about restructurization for property credit and real estate is one of interesting issue to be discussed from the jurisdical view. Recently, the government have provided various kinds of restructurization for property credit and real estate which is the best step to solve non performance loan. However, the solution of loan must be put into in action by considering for the persistence of business for property sector and real estate. The consequency of restructurization is enabled the changes of position and role for capital management and loan structure.
\end{abstract}

\section{Pendahuluan}

- Sektor properti dan perbankan nasional dibangun di atas pondasi yang sangat rapuh dengan paradigma salah kaprah sejak 1980an. Pemerintah, pengembang dan pihak perbankan sejak lama terjebak, melihat bisnis properti hanya dari sisi penawaran, sedangkan sisi permintaan diabaikan. Perumahan sebagai kebutuhan pokok, dilihat sebagai lahan bisnis yang sangat menjanjikan oleh para investor. Prospek usaha sektor properti, ditambah keyakinan akan kuatnya pondasi ekonomi nasional, ${ }^{1}$ sebelum terjadinya krisis ekonomi yang berawal pada pertengahan 1997, mendorong sikap kalangan bisnis swasta berlomba-lomba mencari kredit luar negeri dengan bunga yang lebih murah tanpa adanya upaya hedging.

Ekspektasi yang berlebihan terhadap kondisi properti Indonesia, mengakibatkan pihak perbankan dengan mudah mengucurkan kredit ke sektor properti di luar batas kendali. Berdasarkan catatan Dewan Pimpinan Pusat Real Estate Indonesia, utang di sektor properti dan real estate mencapai

1Angka pertumbuhan ekonomi tinggi, tingkat inflasi relatif rendah, nilai tukar rupiah terhadap Dollar Amerika Serikat dapat dianggap stabil untuk kurun waktu yang panjang, sehingga menjadikan arus masuk modal dari luar negeri berupa kredit sektor swasta dianggap lebih murah dibandingkan dengan kredit rupiah dalam negeri. 
Rp 70 Triliun. Dari jumlah tersebut yang tergolong kredit lancar hanya mencapai Rp 25.4 Triliun atau $36,3 \%$, selebihnya merupakan kredit bermasalah. ${ }^{2}$ Sebagian besar dana jangka pendek digunakan untuk membiayai bisnis properti yang merupakan bisnis yang bersifat jangka panjang. ${ }^{3}$

Rekomendasi yang dapat ditawarkan untuk menyelesaikan krisis di sektor properti adalah restrukturisasi. Kesepakatan demi kebaikan bersama akan tercapai, apabila debitor dan para kreditor mau dan berani duduk bersama untuk menyetujui penyelesaian utang piutang. Program ini merupakan alternatif untuk memperkuat sektor riil, khususnya sektor properti dalam rangka membangun kembali perekonomian nasional, yang pelaksanaannya harus menjadi skala prioritas dan terintegrasi. Restrukturisasi kredit hanya dapat dilakukan dengan pendekatan analisis ekonomi dalam hukum. Hukum mempengaruhi sesuatu melalui sanksi, seperti penjara atau ganti kerugian. Untuk itu, bagaimana restrukturisasi kredit properti dan real estate dilaksanakan untuk menyelesaikan non performance loans? Bagaimana akibat hukum restrukturisasi kredit properti dan real estate terhadap kreditor bank maupun debitor pengembang?

\section{Perkembangan Industri Properti di Indonesia}

Perkembangan properti di Indonesia termasuk masih baru. Industri real estate mulai ada sejak pemerintahan orde lama, yang dilaksanakan oleh pemerintah daerah. Industri properti mengalami perkembangan pesat pada 1980-an, setelah Indonesia memasuki Pembangunan Lima Tahun III.

Sama seperti yang terjadi di negara lain, industri properti di Indonesia berkembang setelah pemerintah memberikan perhatian khusus bidang perumahan dengan dibentuknya Menteri Perumahan Rak'yat. Pemerintah merupakan pihak pertama yang melakukan program pembangunan perumahan, melalui program yang disebut Perumahan Nasional atau disingkat dengan Perumnas. ${ }^{4}$

Perkembangan industri properti di Indonesia dari sisi demand, mengalami booming bersamaan dengan semakin meningkatnya kemampuan daya beli masyarakat. Dari sisi supply semakin banyak dana yang tersedia bagi industri properti yang disediakan oleh pihak perbankan, terutama setelah dikeluarkannya paket deregulasi di bidang perbankan. Jumlah bank di indonesia bertambah banyak, hingga mencapai lebih dari 200 bank.

2.Lukman Purnomosidi. "Restrukturisasi Hutang Pengembang RS/RSS". Makalah Seminar Nasional Prospek Investasi Properti Pasca Rekapitulasi Perbankan. Semarang. Jawa Tengah: Dewan Pimpinan Daerah Real Estate Indonesia. 15 April 1999. HIm. 1-10.

${ }^{3}$ Theo L. Sambuaga. Makalah Pidato Pengarahan Seminar Nasional Prospek/nvestasi Properti Pasca Rekapitulasi Perbankan. Semarang. Jawa Tengah: Dewan Pimpinan Daerah Real Estate Indonesia. 15 April 1999. HIm. 3.

${ }^{4}$ Sambutan Ketua Badan Pengawas Pasar Modal Seminar Nasional Rekapitalisasi Perbankan Nasional dan Restrukturisasi Kredit Sektor Properti. Jakarta. 25 Februari 1999. HIm. 1. 
Bersamaan dengan kondisi booming, semakin banyak pengusaha yang bergerak di bidang industri properti, bagaikan jamur yang tumbuh subur di musim hujan, sehingga mengakibatkan over supply. Kondisi ini tidak didukung oleh persiapan dan perencanaan yang matang, sehingga terjadi persaingan yang tidak sehat. Praktek-praktek yang penuh dengan nuansa Korupsi Kolusi Nepotisme menimbulkan banyak kasus, khususnya di bidang pertanahan. ${ }^{5}$

Kondisi pasar yang masih baru mengakibatkan banyak pula pengusaha muda yang pada dasarnya belum siap dan "matang" untuk memasuki industri ini, sehingga hanya melahirkan banyak enterpreneur yang tidak tahan uji dan tahan banting. Akibatnya, banyak social cost terhamburkan yang harus ditanggung oleh masyarakat. Cost of production menjadi tinggi, sehingga harga rumah juga tidak dapat ditekan, dan efisiensi industri rendah. ${ }^{6}$

Struktur pengusaha industri properti didominasi oleh pengusaha menengah dan kecil yang hampir dari segala segi bisnis kurang siap dalam menghadapi badai krisis ekonomi; meskipun pada perkembangannya industri ini telah dimasuki segenap lapisan pengusaha, tidak hanya pengusaha yang tergolong pengusaha lemah, namun pengusaha bermodal sangat kuat pun ikut meramaikan bisnis ini.

Sejak awal industri properti terkesan adanya perencanaan lokasi dan peruntukan lahan yang kurang matang, sehingga tidak terjadi diversifikasi produk yang baik, mengakibatkan produk yang mengarah pada mass product, dan menghilangkan faktor keunggulan-keunggulan tertentu. Akibat lebih lanjut menimbulkan persaingan yang tidak sehat. Pendekatan mass product mengakibatkan pula kelumpuhan bersama khususnya setelah terjadinya krisis moneter 1997.

Dari struktur industri, terutama segi permintaan (demand), menunjukkan elastisitas industri properti terhadap kondisi ekonomi makro hampir mendekati satu. Artinya, apabila kondisi ekonomi makro membaik, maka industri ini juga akan membaik. Sebaliknya, apabila kondisi ekonomi makro menurun, maka industri ini akan mengalami penurunan. Hal ini mengakibatkan banyaknya faktor dependen atau ketergantungan industri properti terhadap kondisi perekonomian secara keseluruhan. Untuk mengatasi hal ini, jalan satu-satunya adalah melalui diversifikasi, baik dari segi pendanaan, produk, dan pengusaha. Sayangnya, industri properti di Indonesia tidak sempat mengembangkan faktor ini dengan baik.

Di antara 1.709 perusahaan pengembang, $80 \%$ atau 1.470 perusahaan pengembang bergerak di bidang perumahan, dan $14 \%$ bergerak di bidang non perumahan, seperti Gedung Perkantoran, Pusat Perbelanjaan, Apartemen, Kondominium, Kawasan Industri, Hotel, Golf. Pengembang perumahan pada umumnya memiliki utang Rupiah, sedangkan pengembang non perumahan pada umumnya memiliki utang Dollar Amerika Serikat.

$5 /$ bid.

${ }^{6} /$ bid. HIm. 2. 
Di antara 1.470 perusahaan pengembang perumahan, sebanyak $80 \%$ atau 1.205 (seribu dua ratus lima) perusahaan adalah pengembang Rumah Sederhana atau Rumah Sangat Sederhana, selebihnya $18 \%$ atau sebanyak 245 perusahaan merupakan pengembang Rumah Menengah Mewah. Dari 1.470 perusahaan pengembang perumahan, pada umumnya memiliki utang antara $\cdot R p$ juta hingga di atas Rp 50 miliar. Namun dari 1.470 perusahaan, sebanyak 1.205 perusahaan merupakan pengembang Rumah Sederhana atau Rumah Sangat Sederhana, yang pada umumnya memiliki utang antara Rp 750 juta hingga Rp. 10 miliar. Sebagian besar dari pengembang memiliki utang di bank Bank Tabungan Negara.

Data Bank Indonesia 1993 sampai dengan 1997 atau sebelum krisis moneter, pertumbuhan kredit untuk industri properti dan real estate menunjukkan rata-rata pertumbuhan sebanyak $62,3 \%$. Jumlah kredit properti sampai dengan September 1998 dari kredit perbankan telah mencapai $\mathrm{Rp} 72,692$ Triliun atau sekitar $15,9 \%$, dari jumlah ini, tergolong non-performing loans sebanyak $56 \%$.

Sampai dengan akhir 1998 total kredit sektor real estate sebesar Rp 72 Trilyun, dengan komposisi' $27 \%$ atau Rp 20 Trilyun utang Kredit Perumahan Rakyat, dan sejumlah Rp 52 Trilyun atau $73 \%$ adalah utang pengembang. Data awal 1999, menunjukkan posisi kredit konstruksi dan real estate 1.502 Perusahaan Pengembang Perumahan di Indonesia yang berada di bawah Rp 100
Milyar total kredit macet mencapai Rp 5.164 Miliar. $^{7}$

Perusahaan properti dan real estate yang sähamnya tercatat di bursa sebanyak 288 perusahaan, dan jumlah emiten yang tercatat di bursa mencápai 25 perusahaan. Dari jümlah tersebut, jumlah émiten yang harga sahamnya di bawah nilai nominal Rp 500 sebanyak 22 perusahaan atau $88 \%$. Dari segi persentase, dibandingkan dengan industri lainnya, industri properti dan real estate menduduki peringkàt paling tinggi yang diikuti oleh industri keuangan yang mencapai $84,74 \%$. Data yang ada menunjukkan dari 59 perusahaan di bidang industri keuangan, sebanyak 50 perusahaan mengalami nilai pasar saham yang lebih rendah dari nilai nominal. Emiten di bidang industri properti dan real estate juga menduduki ranking tertinggi yang melaporkan pendapatan bersih (net income) negatif, yaitu sebanyak 20 perusahaan atau $80 \%$. Sementara jumlah emiten di bidang industri properti dan real estate yang melaporkan total equity yang negatif terdapat sebanyak 3 perusahaan atau sekitar $12 \%^{8}$

Persoalan Mendasar Bisnis Properti dan Real Estate

Anggapan pemerintah Indonesia bahwa pembangunan kawasan perumahan skala besar akan menciptakan efisiensi pada industri perumahan nasional terbukti keliru. Begitu pula pandangan pihak pengembang dan perbankan yang menganggap bahwa dari 
kalkulasi bisnis, proyek properti skala besar akan lebih menguntungkan dibandingkan dengan proyek skala kecil, ternyata keliru. Secara logika, semakin besar sebuah proyek properti, maka semakin luas tanah yang dibebaskan pengembang. Dengan demikian, semakin besar dana jangka panjang yang harus disediakan oleh pihak perbankan. Apalagi dengan tingkat suku bunga Indonesia yang sangat tinggi, sehingga dapat dipastikan beban biaya bunga (cost of fund) yang harus dibebankan pengembang pada harga rumah akan semakin besar pula.

Dengan perkataan lain, semakin besar proyek properti akan semakin tinggi harga tanah dan harga rumah dijual ke pasar. Hal ini berarti, semakin kecil pula pangsa pasarnya. Sebuah perekonomian dengan suku bunga tinggi, tidak pernah layak mendukung bisnis properti skala besar. Proyek properti skala besar di Indonesia mengandung risiko permodalan, risiko likuiditas, dan risiko pasar yang sangat tinggi, berkaitan dengan lemahnya permodalan dan tingginya suku bunga perbankạn di Indonesia.

Industri properti dan real estate yang sejak awal mengandalkan pendanaan konvensional, yaitu perbánkan, menyebabkan para pengusaha tidak pernah berusaha untuk mencari sumber dana jangka panjang. Hal ini mengakibatkan terjadinya mismatch yang sangat besar, yaitu sumber pembiayaan yang bersifat jangka. pendek digunakan untuk investasi. jangka panjang. Mismatch pembiayaan ini mengakibatkan struktur neraca keuangan industri properti sangat lemah, karena kurang didukung oleh permodalan yang memadai dan kurangnya sumber pembiayaan jangka panjang. Kondisi ini mengakibatkan kurang tahannya perusahaan properti dalam menghadapi krisis.

Proyek properti skala besar dengan sumber dana dalam negeri belum layak digarap di Indonesia. Kecuali dengan modal langsung yang dibawa masuk oleh investor asing. Prakteknya, justru pihak perbankan yang begitu getol membiayai proyek properti skala besar. Bahkan, terbukti sebagian besar pemilik bank ikut bermain di sektor properti skala besar. $^{9}$

Sejak satu dekade terakhir, perbankan nasional dimanfaatkan sebagai akses untuk menarik utang luar negeri berjangka pendek, dan digunakan sebagai basis pembiayaan sektor properti yang bersifat jangka panjang secara besar-besaran. Hal ini merupakan salah satu pemicu krisis multi dimensi dan kehancuran perekonomian Indonesia. Penyalahgunaan penggunaan dana sektor perbankan nasional dan utang luar negeri jangka pendek pada akhirnya bermuara pada crash sektor properti dan sektor perbankan itu sendiri.

Awal 1993 merupakan pergeseran alokasi krèdit dari sektor produktif (industri). ke sektor konsumtif dan spekulatif (properti). Ekspansi kredit perbankan menjadi tidak terkendali ke sektor properti, dan jauh melampaui laju kredit sektor industri. ${ }^{10}$ Gejala ini di satu sisi telah memperlemah kinerja ekspor, namun di sisi

9Panangian Simanungkalit. "Rekapitulasi Perbankan dan Restrukturisasi Kredit Properti". Makalah Seminar Rekapitalisasi Perbankan Nasional. (Jakarta: Intact Consulting Indonesia. 25 Februari 19990). HIm. 7. ${ }^{10} \mathrm{lbid}$. HIm. 5. 
lain justru meningkatkan laju impor, berupa bahan bangunan, yang akhirnya bermuara pada pengurasan devisa nasional. Akibatnya nampak tanda-tanda pemanasan ekonomi (over heating), yaitu meningkatnya tingkat inflasi pada 1995.

Sejak saat itu arah perekonomian Indonesia mulai bergeser dari export led economy ke consumption driven economy. Kenyataan membuktikan bahwa kekhawatiran banyak pihak terhadap angka defisit neraca transaksi berjalan semenjak 1994, terbukti terus meningkat hingga 1996, dan akhirnya mencapai angka $4 \%$ dari nilai Produk Domestik Bruto pada 1997. " Selanjutnya, ketika spekulan mata uang menguji kekuatan fundamental perekonomian Thailand pada Desember 1996, dengan berkeyakinan bahwa fondasi perekonomian Indonesia lebih kokoh dibandingkan dengan Thailand, hampir semua elit politik Indonesia mengatakan bahwa goncangan krisis ekonomi Thailand, meskipun dapat terjadi di Indonesia, namun tidak akan separah yang dialami Thailand.

Paparan di atas menyisakan pertanyaan, bagaimana dan di mana sebenarnya peran para ekonom senior Bank Indonesia selaku otoritas moneter dalam merancang sistem pengendalian ekonomi makro selama ini. Disamping itu Pemerintah Daerah dan Badan Pertanahan Nasional seakan-akan bekerja tanpa konsep, perencanaan, dan pengendalian dalam bidang tata ruang dan pertanahan. ljin lokasi dalam jumlah ratusan diberikan dengan sangat mudah, bahkan ribuan hektar kepada konglomerat yang tidak mempunyai reputasi di bidang proyek perumahan skala besar. Padahal dengan logika ekonomi sederhana, penguasaan tanah besar-besaran akan menciptakan pasar tanah yang bersifat oligopolistik, sehingga muncul distorsi pasar. Bahkan sepanjang sejarah, penguasaan tanah secara besarbesaran oleh pihak swasta di manapun di dunia, tidak akan mungkin secara efisien menghasilkan keuntungan, tetapi hanya melahirkan high cost economy pada industri perumahan.

Pemerintah Daerah dan Badan Pertanahan Nasional terkesan hanya memandang persoalan sektor properti dari sisi administrasi, tanpa melihat dari perspektif ekonomi makro dan mikro. Indikasi kuatnya tarikan kepentingan pribadi para oknum pejabat pemerintah Daerah dan Badan Pertanahan Nasional yang bercokol kuat di balik ekspansi bisnis properti, menyebabkan pilihan kepentingan pribadi akhirnya mengalahkan kepentingan negara.

\section{Restrukturisasi: Analisis Ekonomi dalam Hukum}

Restrukturisasi perusahaan merupakan perubahan bentuk hukum, susunan organisasi maupun modal. suatu perusahaan. ${ }^{12}$ Melalui restrukturisasi, suatu perusahaan berupaya untuk merubah kinerja

"I/bid.

${ }^{12}$ John D. Martin. et. al. 1995. Dasar-dasar Manajemen Keuangan. Jakarta: Raja Grafindo Persada. HIm. 484. Lihat pula Heindjrachman Ranu Pandojo. et. al. Pengantar Ekonomi Perusahaan. Yogyakarta: BPFE. 1982. HIm. 189. 
perusahaan menjadi lebih baik. Bambang Riyanto berpendapat suatu restrukturisasi dibedakan dalam tiga bentuk: ${ }^{13}$ Pertama, Restrukturisasi yuridis, perusahaan melakukan perubahan bentuk hukum. Kedua, Restrukturisasi intern, perusahan melakukan perubahan struktur organisasi perusahaan. Ketiga, Restrukturisasi keuangan, perusahaan melakukan perubahan menyeluruh terhadap struktur modal karena perusahan tidak solvabel.

Restrukturisasi kredit hanya dapat dilakukan dengan pendekatan analisis ekonomi dalam hukum. Hukum mempengaruhi sesuatu melalui sanksi, seperti penjara atau ganti kerugian. Aspek memaksa dari hukum mengasumsikan orang tahu mengenai konsekuensinya. Kewajiban dari hukum tidak lain dari prediksi bahwa jika seseorang berbuat atau menghindarkan diri dari sesuatu, akan mengalami penderitaan atau kesusahan, misalnya akibat keputusan pengadilan. ${ }^{14}$

. Legislator dan hakim percaya bahwa orang akan menjawab ancaman dengan memodifikasi tingkah lakunya untuk meminimalisasi ongkos dari ketaatan dan sanksi. Disadari bahwa dunia ekonomi mulai dengan perdagangan. bebas, dan dunia hukum mulai dengan peraturan. Dua disiplin ini selalu melahirkan different prescription mengenai interaksi sosial. ${ }^{15}$
Analisis ekonomi menentukan pilihan dalam kondisi kelangkaan (scarcity). Dalam kelangkaan, ekonomi mengasumsikan bahwa individu atau masyarakat akan atau harus berusaha .untuk memaksimalkan apa yang ingin capai dengan melakukan sesuatu sebaik mungkin dalam keterbatasan sumber daya. Dalam hubungan dengan positive analysis dari hukum, pertanyaan yang muncul adalah apabila kebijakan hukum dilaksanakan, prediksi apa yang dapat dibuat yang mempunyai akibat ekonomi. Orang akan memberikan reaksi terhadap insentif atau disentif dari kebijakan (hukum) tersebut.

Pendekatan analisis ekonomi dalam hukum di negara-negara civil law bukan tanpa prospek. Para ahli hukum semakin terbuka kepada pemikiran baru dalam mengembangkan hukum, antara lain dengan memakai pendekatan baru ini. Penegakan hukum tidak semata-mata didasarkan pada perasaan keadilan, tetapi juga pada perhitungan costbenefit ratio. ${ }^{16}$

Penyelesaian kredit bermasalah sangat tergantung itikad debitor dan kreditor sebagai kunci bagi terselenggaranya perundingan kembali bagi penyelesaian utang debitor képada kreditor. Upaya penyelesaian utang pengembang properti dapat dilakukan dengan penjadwalan kembali, melalui penundaan pembayaran utang secara kontraktual (con-

${ }^{13}$ Bambang Riyanto dalam Hidjrachman Ranupandojo et. al. 1989. Pengantar Ekonomi Perusahaan. Buku 2. Yogyakarta: BPFE. HIm. 189.

${ }^{14}$ Erman Rajagukguk. "Analisis Ekonomi dalam Hukum Kontrak." Makalah. Tanpa Tahun. HIm. 36.

${ }^{15}$ /bid. Mengutip dari H Easterbook. "The Inevitability of Law and Economics". Legal Education Review. Vol 1 No. 1 Tahun 1989. HIm. 3-4.

${ }^{16}$ /bid. HIm. 39. 
tractual moratorium). Upaya ini dapat ditempuh terutama apabila ada cukup alasan bahwa debitor mempunyai track record bagus dalam mentaati semua ketentuan perjanjian kredit yang telah dibuat pada masa sebelum terjadinya krisis moneter. ${ }^{17}$

Restrukturisasi kredit merupakan salah satu alternatif yang dipandang cocok bagi penyelesaian masalah kredit macet di sektor riil. Namun demikian alternatif ini harus ditempuh dengan beberapa pertimbangan: Pertama, Untuk kelangsungan kehidupan dan kesehatan perbankan dimana sumber utama operasi atau pendapatan bank ${ }^{18}$ berasal dari bunga pinjaman, sehingga apabila tidak diambil langkah-langkah pembenahan, maka akan semakin memperburuk kinerja bank. Bahkan, program rekapitalisasi perbankan tidak akan berhasil, yang berakibat fatal bagi eksisitensi bank. ${ }^{19}$

Kedua, Untuk kelangsungan perusahaan debitor. Ketika perusahaan dalam keadaan berhenti membayar utang-utangnya kepada bank, maka harus diputuskan apakah debitor akan dimohonkan untuk dinyatakan pailit, atau tetap dipertahankan melalui reorganisasi. Keputusan ini pada dasarnya sangat tergantung pada pilihan mana yang terbaik, dalam arti tindakan itu akan memberikan manfaat terbesar untuk kepentingan kreditor dan debitor. ${ }^{20}$

Apapun tindakan yang diambil terhadap debitor, doktrin dasar keadilan (fairness) yang menyatakan bahwa klaim harus diakui urutan prioritasnya menurut hukum dan perjanjian harus dilaksanakan. ${ }^{21}$ Perlindungan terhadap debitor (pengembang properti) harus dilakukan dengan memperhatikàn kepentingan para stake holder dari debitor yang masih menghendaki kelangsungan hidup perusahaan debitor, mengingat banyak pihak yang terlibat dalam restrukturisasi kredit sektor properti.

Mengingat banyaknya kepentingan yang terlibat dengan debitor, alternatif guna memberikan kesempatan kepada perusahaanperusahaan yang tidak mampu membayar utang-utangnya dibutuhkan, sehingga perusahaan debitor dapat kembali berada dalam keadaan mampu membayar utangutangnya. ${ }^{22}$

Ketentuan Dewan Pimpinan Pusat Real Estate Indonesia mensyaratkan pengembang properti harus berbentuk Perseroan Terbatas, sehingga ketentuan dalam Undang-Undang Nomor 1 Tahun 1995 tentang Perseroan Terbatas merupakan landasan utama bagi restrukturisasi kredit sektor properti. UndangUndang Nomor 1 Tahun 1995 tentang Perseroan Terbatas mengakui para pihak yang berkaitan dengan perseroan adalah:

${ }^{17}$ Fred B.G. Tumbuan. Op. Cit. Hlm. 13-14.

${ }^{18}$ Sekitar $65 \%-80 \%$ (enam puluh lima persen sampai dengan delapan puluh persen).

${ }^{19}$ Rijanto. Op. Cit. HIm. 3.

${ }^{20} \mathrm{~J}$. Fred Watson dan Eugene F. Brigham. Terjemahan Alfons Srinita. 1994. Dasar-dasar Manajemen Keuangan. Jakarta: Erlangga. HIm. 321.

${ }^{21}$ ibid.

${ }^{2}$ Sutan Remy Sjahdeini. "Perlindungan Debitur dan Kreditur, Dampak Undang-Undang Kepailitan terhadap Perbankan". Artikel Jurnal Hukum Bisnis. Vol. 5/1999. HIm. 6. 
kepentingan perseroan, kepentingan pemegang saham minoritas, kepentingan karyawan perseroan, kepentingan masyarakat, kepentingan persaingan sehat dalam melakukan usaha. ${ }^{23}$

Kepentingan masyarakat berkaitan dengan resrtukturisasi kredit di bidang properti dan real estate, yang apabila tidak berhasil dilaksanakan dengan baik dan benar merasakan dampaknya secara langsung, antara lain: Pertama, Masyarakat pencari kerja. Berdasarkan catatan satuan tugas Real Estate Indonesia sebuah Rumah Sangat Sederhana mampu memberikan pekerjaan pada sepuluh juta orang tenaga kerja. Kedua, Masyarakat pemasok barang dan jasa serta masyarakat yang tergantung hidupnya dari pasokan barang dan jasa debitor. Berdasarkan catatan satuan tugas Real Estate Indonesia sektor ini mampu menggerakkan seratus empat usaha terkait. ${ }^{24} \mathrm{Ketiga,} \mathrm{Para} \mathrm{pemegang}$ saham pada perusahaan properti, terutama perusahaan publik..$^{25}$

Negara pun berkepentingan untuk tidak kehilangan sumber pajak yang berasal dari perusahaan properti dan real estate. Oleh karena itu, negara berkepentingan agar perusahaan properti dan real estate tetap terjaga eksistensinya. Disamping itu kebutuhan perumahan yang merupakan kebutuhan dasar masih jauh dari cukup, sehingga pembangunannya tidak hanya menjadi tanggung jawab seluruh masyarakat, namun pemerintah berkewajiban menciptakan iklim pembangunan kondusif bagi terselenggaranya pembangunan perumahan berkelanjutan.

\section{Tawaran Penyelesaian Kredit Sektor Properti}

Secara teknis maupun konvensional apabila ada tanda-tanda deviasi yang menimbulkan kredit bermasalah dalam dunia perbankan, maka manajemen bank akan segera melakukan peninjauan kembali terhadap kredit yang diberikan (loan review) atas variabel-variabel yang menjadi sumber sinyal tersebut. Sumber masalah dapat berasal dari kondisi keuangan, kondisi kegiatan debitor, sikap debitor, sikap bankir, dan lingkungan perbankan, yang dilanjutkan dengan kredit identifikasi, sehingga diketahui intensitas deviasinya. Apabila masih dalam jangkauan penyelamatan atau penyehatan kredit, maka langkah strategisnya adalah penyelamatan kredit. Apabila tidak berhasil, maka manajemen bank segera memutuskan untuk melakukan strategi pemutusan kredit berupa:26 Pertama, Negosiasi bank dengan

\section{${ }^{23}$ Ibid.}

${ }^{24}$ Lukman Purnomosidi. "Restrukturisasi Utang Sektor Real Estate menuju Pemulihan Ekonomi". Makalah Seminar Nasional Rekapitalisasi Perbankan dan Restrukturisasi Kredit Sektor Properti. Jakarta: 25 Februari 1999. HIm. 8.

${ }^{25}$ Data statistik di Pasar Modal Indonesia menunjukkan sampai 31 Desember 1998, dari 288 emiten, 25 diantaranya merupakan perusahaan properti dan real estate.

${ }^{26}$ H. Muh. Tjoekam. 1998.Perkreditan Bisnis Inti dan Komersial. Jakarta: Gramedia Pustaka Utama. HIm. 292. 
kreditor. Bank dapat melakukan penguasaan hasil usaha, baik seluruhnya atau sebagian, sewa barang agunan, atau mencarikan mitra usaha yang berjalan baik. Semua hasil ini digunakan untuk menurunkan utang debitor.

Kedua, Pengambilalihan manajemen perusahaan, dimana bank bersama nasabah mencari perusahaan yang mampu mengambil alih, baik berupa anak angkat, joint venture, aliansi, akuisisi maupun merger. Kemungkinan lainnya adalah melikuidasi agunan yang tidak terkait dengan proses usaha. Ketiga, Penyerahan hak penagihan piutang kepada badan-badan resmi yang secara yuridis berhak menagih piutang, seperti Panitia Urusan Piutang Negara, Pengadilan Negeri, Badan Arbitrase Nasional Indonesia. Keempat, Debitor macet dinyatakan pailit karena berhenti membayar utang-utangnya (insolvency) melalui pangajuan permohonan pernyataan pailit ke Pengadilan Niaga.

Strategi penyelesaian kredit bermasalah sebagaimana dipaparkan di atas tidak selamanya membuahkan hasil seperti yang diharapkan. Menarik untuk dikemukakan penelitian H.P. Panggabean berkaitan dengan peranan pengadilan terhadap kredit macet perbankan. ${ }^{27}$ Hasil penelitian menunjukkan bahwa peranan pengadilan di bidang non litigasi seperti sommasi, fiat eksekusi, perintah pengosongan dan penetapan sita tidak menunjukkan tingkat kuantitas tinggi. Dari 3.648 perkara yang ditangani sepuluh Pengadilan Negeri selama lima tahun, pelaksanaan lelang eksekusi hanya mencapai jumlah $1,67 \%$, dan untuk pengosongan hanya sejumlah $0,14 \%$. Berdasarkan data tersebut, Panggabean mengilustrasikan bahwa peranan pengadilan dalam menanggulangi masalah perjanjian kredit tidak potensial untuk mendukung perbankan mengatasi masalah kredit macet. ${ }^{28}$

Paparan di atas menunjukkan perkembangan kredit bermasalah (non performing loans) sektor properti yang semakin memburuk, dan kondisi ekonomi makro yang belum membaik, sehingga kebijakan otoritas moneter menyadari bahwa program rekapitalisasi bank tidak akan berhasil apabila tidak disertai dengan program restrukturisasi perkreditan. ${ }^{29}$ Bagi perusahaan dengan prospek usaha yang masih baik, biasanya tidak serta merta mengajukan permohonan pernyataan pailit, karena dengan cara ini kreditor belum tentu dapat memperoleh pengembalian atas pinjaman yang diberikan kepada debitor. ${ }^{30}$ Restrukturisasi utang pengembang seharusnya ditempuh berdasarkan inisiatif dan itikad baik antara pihak pengembang bersama pihak perbankan untuk menyelesaikan, secara bilateral dengan prinsip win-win atau lose-lose solution.

${ }^{27}$ H.P. Panggabean. "Betbagai Masalah Yuridis yang Dihadapi Perbankan Mengamankan Pengembalian Kredit yang Disalurkannya". Varia Peradilan. No. 80 Tahun 1992. HIm. 104-125.

${ }^{28} \mathrm{lbid}$.

${ }^{29}$ Rijanto. "Rekapitalisasi Perbankan." Makalah Seminar Nasional Rekapitalisasi Perbankan dan Restrukturisasi Kredit Properti. Jakarta: Impact Consulting Indonesia. 25 Februari 1999. HIm. 1.

${ }^{30}$ Sri Indrastuti \& Christian Theo. "Debt Conversion (Kompensasi Utang." Jurnal Penyelesaian Utang. Jakarta: No. 04.17 Maret 1999. 
Industri properti dan real estate juga harus dapat melepaskan ketergantungan dirinya dari sumber pembiayaan konvensional (kredit perbankan), melalui sumber-sumber pembiayaan lainnya yang lebih bersifat jangka panjang. Salah satu financial engineering (rekayasa keuangan) yang dapat dipertimbangkan adalah melalui pengetatan kebijakan dalam pengucuran kredit, sehingga mismatch pembiayaan yang telah terjadi dapat dijembatani, sehingga antara sumber pembiayaan dan investasi menjadi seimbang.

Kebijakan untuk melakukan restrukturisasi terhadap industri perbankan oleh pemerintah diambil dengan tujuan sebagai berikut: Pertama, Menjaga agar sistem pembayaran di dalam perekonomian dapat berjalan. Kedua, Menggerakkan kembali dunia usaha, sehingga sektor riil dapat melakukan kegiatan bisnis. Ketiga, Mengembalikan kepercayaan terhadap perekonomian nasional terutama di mata investor asing dan lender.

Namun demikian, upaya DPP REI pada Januari 1999 dalam rangka restrukturisasi utang para pengembang dengan membentuk tim Satgas khusus untuk penyelesaian utang, belum menunjukkan hasil memuaskan. Perusahaan pengembang yang mendaftarkan diri pada Program Prakarsa Jakarta baru 120, padahal jumlah pengembang yang memiliki persoalan utang tidak kurang dari 1.470 perusahaan.

\section{Kebijakan Bank Tabungan Negara dalam Restrukturisasi Kredit Sektor Properti dan Real Estate}

Bank Indonesia pada Nopember 1998 mengeluarkan surat Keputusan tentang Restrukturisasi Kredit yang harus dilaksanakan oleh perbankan nasional dengan tujuh alternatif, yaitu: Pertama, Penurunan suku bunga kredit. Kedua, Pengurangan tunggakan bunga kredit. Ketiga, Pengurangan tunggakan pokok kredit. Keempat, Perpanjangan jangka waktu kredit. Kelima, Penanaman fasilitas kredit. Keenam, Pengambilalihan aset pengembang sesuai ketentuan. Ketujuh, Konversi kredit menjadi penyertaan modal sementara pada perusahaan pengembang.

Surat Keputusan Bank Indonesia menegaskan restrukturisasi kredit hanya dapat dilakukan terhadap pengusaha yang masih memiliki prospek usaha, namun mengalami kesulitan pembayaran utang pokok atau bunganya. Untuk menilai apakah sebuah proyek yang dikelola sebuah perusahaan masih memiliki prospek, pihak bank memerlukan bantuan jasa Konsultan Properti independen.

Menurut pendapat PSPI, dalam rangka restrukturisasi kredit, untuk dapat menyelesaikan utang piutang secara cepat dan efektif, maka pengelompokan sektor usaha merupakan alternatif terbaik. Mengingat setiap sektor bisnis memiliki karakter yang khas sehingga dengan membahas persoalan masing-masing sektor usaha, pihak perbankan dapat mengetahui secara jelas sebab-sebab kesulitan debitor.

Sebagai contoh penyelesaian utang sektor properti perbankan di masa lalu justru paling gencar mengucurkan kredit ke sektor properti karena, agunan sektor properti dinilai aman. Padahal sektor properti sangat rentan terhadap gejolak perekonomian, apalagi dengan suku bunga tinggi dan pihak bank juga harus sadar terlalu berani berekspansi di sektor properti dengan modal dana jangka pendek. Sekarang setelah sektor properti terpuruk begitu dalam, 
pihak Bank seakan-akan tidak mau ikut menanggung risiko.

Skema penyelesaian kredit bermasalah sektor properti dari perspektif pihak perbankan disebut sebagai Property. Bad Debt Restructuring (PBDR). Skema ini secara teknis tetap mengacu pada Surat Keputusan Bank Indonesia Nomor 31/150/KEP/DIR yang mulai berlaku 31 Desember 1998.

Secara garis besar langkah-langkah PBDR yang diusulkan terbagi dalam sembilan tahap: Pertama, Pembentukan tim PBDR. Kedua, Penilaian Kriteria Kredit dan Status Proyek. Ketiga, Pelaksanaan Audit Proyek dan Penilaian Aset. Keempat, Rekomendasi Konsultan Kepada Pihak Bank. Kelima, Restrukturisasi PaketA. Keenam, Restrukturisasi Paket B. Ketujuh, Pengawasan Proyek. Kedelapan, Pembentukan Aset Manajemen Unit. Kesembilan, Property. Selling and Marketing

Kebijakan penyelesaian utang sektor properti dan real estate yang dilaksanakan oleh Bank Tabungan Negara dalam rangka restrukturisasi meliputi: nọvasi, subrogasi, penjualan jaminan kredit, penagihan utang melalui pengadilan negeri, penagihan piutang melalui BUPLN, pelelangan agunan kredit langsung dengan kurator lelang, upaya hukum terhadap jaminan pribadi (bortgtocht), dan kepailitan.

\section{Novasi}

Novasi (pembaruan utang) adalah suatu perjanjian dimana perikatan yang sudah ada dihapuskan sekaligus diadakan suatu perikatan baru. Berdasarkan Pasal 1413 Kitab Undang-Undang Hukum Perdata, novasi terjadi dalam tiga bentuk:31 Pertama, Debitor dan kreditor mengadakan perjanjian baru, dan perjanjian lama dihapuskan (novasi objektif). Kedua, Apabila terjadi penggantian debitor, maka debitor lama dibebaskan dari perikatannya (novasi subjektif pasif). Keempat, Apabila terjadi penggantian kreditor, maka kreditor lama dibebaskan dari perikatannya (novasi subjektif aktif)

Pasal 1414 sampai dengan Pasal 1418 Kitab Undang-Undang Hukum Perdata mengatur syarat-syarat novasi, yaitu: Pertama, Novasi dilakukan oleh, orang yang cakap mengadakan perikatan. Kedua, Kehendak.dan pelaksanaan novasi dinyatakan secara tegas dengan sebuah akta. Ketiga, Penunjukan debitor baru. Keempat, Pemindahan atau delegasi yang mengikat dirinya terhadap kreditor. Kelima, Kreditor tidak dapat menuntut debitor dari dibebaskannya utang.

Dalam restrukturisasi industri properti dan real estate, novasi merupakan pengalihan utang atau kewajiban debitor (berikut aset) baik sebagian atau seluruhnya kepada pihak lain (transfer of borrower atau alih debitor). Langkah ini ditempuh dengan tujuan mengganti debitor yang sudah tidak mampu melanjutkan proyeknya dengan debitor baru yang memiliki kemampuan dan kredibilitas baik, sehingga usaha debitor menjadi baik dan sehat kembali.

Kriteria yang harus diterapkan bagi debitor baru adalah: Pertama, Debitor baru harus nyatanyata memiliki itikad baik untuk memenuhi kewajiban kepada bank. Kedua, Debitor baru

${ }^{31}$ Mariam Darus Badrulzaman. et. al. Kompilasi Hukum Perikatan. (Bandung: Citra Aditya Bakti. 2001). HIm. 133. 
tidak terafiliasi dengan debitor lama. Ketiga, Prospek usaha debitor baru tergolong baik. Keempat, Kualitas kolektibilitas kredit adalah. sub standard (kurang baik), doubtful (diragukan), dan bad debt (macet).

\section{Subrogasi}

Subrogasi adalah penggantian kedudukan kreditor oleh pihak ketiga. Pasal 1400 Kitab Undang-Undang Hukum Perdata mengatur penggantian terjadi dengan pembayaran yang diperjanjikan atau karena ditetapkan oleh undang-undang.

Apabila pihak ketiga melunaskan utang debitor kepada kreditor yang asli, maka lenyaplah hubungan hukum antara debitur dengan kreditor asli. Namun, pada saat yang sama hubungan hukum tersebut beralih kepada pihak ketiga yang melakukan pembayaran kepada kreditor asli. Dengan pembayaran ini, perikatan tidak lenyap, namun terjadilah pergeseran kedudukan kreditor kepada orang lain.

Subrogasi adalah penggantian hak-hak bank oleh pihak ketiga berdasarkan akta notaris, karena pihak ketiga membayar seluruh utang debitor kepada pihak ketiga yang menggantikan kedudukan bank. Debitor atau pihak ketiga mengajukan permohonan pembaharuan utang secara tertulis. Tujuannya adalah mengalihkan hak tagih kreditor kepada pihak ketiga dengan kompensasi tunai atau dalam bentuk lainnya.

Kriteria bagi debitor yang digantikan hakhaknya adalah: Pertama, Debitor tidak kooperatif. Kedua, Usaha debitor tidak memiliki prospek yang baik. Ketiga, Kualitas kolektibilitas kredit adalah sub standard (kurang lancar), doubtful (diragukan), dan loss (macet).

\section{Penjualan Jaminan Kredit}

Penjualan jaminan kredit merupakan kesepakatan antara bank dengan debitor untuk menjual sebagian dan atau seluruh jaminan kepada pihak ketiga sebagai pelunasan sebagian dan atau seluruh kredit.

Tujuan penjualan jaminan kredit adalah agar kreditor mendapat pelunasan seluruh dan atau sebagian kewajiban debitor dengan pembayaran tunai dari penjualan jaminan debitor; kreditor terhindar dari tuntutan debitor atas penjualan jaminan kreditor; kreditor mendapatkan fresh money; kolektibilitas kreditor menjadi baik.

Kriteria yang ditetapkan bagi penjualan jaminan kredit adalah: Pertama, Diutamakan jaminan tambahan. Kedua; Agunan atau aset yang tersisa masih mengcover terhadap total kewajiban sesuai dengan ketentuan bank. Ketiga, Kualitas kolektibilitas aset adalah sub standard (kurang lancar), doubtful (diragukan), dan loss (macet).

Sedangkan persyaratan penjualan jaminan kredit meliputi: Pertama, Hasil penjualan agunan langsung digunakan untuk membayar sebagian dan atau seluruh kewajiban dengan urutan prioritas pembayaran sesuai dengan ketentuan bank. Kedua, Pelepasan hak atau penyerahan dokumen jaminan setelah pembayaran hasil penjualan efektif mengurangi dan atau melunasi kewajibannya.

\section{Penagihan Utang melalui Pengadilan Negeri}

Upaya penagihan piutang melalui pengadilan negeri berupa eksekusi hak tanggungan terhadap jaminan kredit yang 
pembebanan hak tanggungannya telah diikat sempurna dengan petitum dilakukan eksekusi jaminan kredit melalui lelang atau dijual sendiri oleh bank. Dalam hal jaminan kredit tidak dibebani hak tanggungan dengan sempurna, maka upaya penyelesaian kredit bermasalah melalui Pengadilan Negeri dimaksud dalam bentuk gugatan perdata biasa.

Tujuan penagihan utang melalui Pengadilan Negeri adalah:. Pertama, Kreditor mendapat pelunasan seluruh dan atau sebagian kewajiban debitor dengan pembayaran tunai dari penjualan jaminan debitor. Kedua, Kreditor terhindar dari tuntutan debitor atas penjualan jaminan kreditor. Ketiga, Kreditor mendapat dana segar. Keempat, Meningkatkan kualitas portofolio kreditor menjadi baik.

Kriteria penagihan utang melalui Pengadilan Negeri adalah debitor tidak kooperatif, prospek usaha debitor tidak baik, dan kualitas kolektibilitas kredit golongan loss (macet).

Persyaratan penagihan utang melalui pengadilan negeri adalah: Pertama, Telah dilakukan upaya-upaya penagihan melalui surat peringatan atas wanprestasi debitor. Kedua, Kreditor mengajukan gugatan wanprestasi kepada debitor melalui pengadilan negeri atas kelalaian sebagian dan atau seluruh kewajiban debitor. Ketiga, Kreditor meminta bantuan pengadilan negeri untuk melakukan sita jaminan debitor yang telah diikat secara sempurna dan' dilampiri dengan salinan: Akta perjanjian kredit yang dibuat di depan notaris di Indonesia, Rekening Koran debitor, Akta pembebanan hak tanggungan, Sertifikat hak tanggungan yang sampulnya berkepala "Demi keadilan berdasarkan Ketuhanan Yang Maha Esa", Sertifikat tanah,
Izin Mendirikan Bangunan yang berada di atas tanah yang dijaminkan.

\section{Penagihan Piutang melalui BUPLN}

Merupakan upaya penyelesaian kredit bermasalah yang pelaksanaannya dilakukan olek KP3N, yang dapat dilakukan meskipun kredit belum dibebani hak tanggungan maupun telah dibebani hak tanggungan.

Tujuan yang diharapkan dari kebijakan ini adalah: Pertama, Kreditor dapat pelunasan seluruh atau sebagian kewajiban debitor dengan pembayaran tunai dari penjualan jaminan debitor. Kedua, Kreditor terhindar dari tuntutan debitor atas penjualan jaminan kreditor. Ketiga, Kreditor mendapatkan dana segar. Keempat, Meningkatkan portofolio kreditor menjadi baik.

Kriteria penagihan utang melalui BUPLN adalah debitor tidak kooperatif, prospek usaha debitor tidak baik, dan kualitas kolektibilitas kredit golongan loss (macet), sedangkan persyaratan yang harus dipenuhi adalah telah diupayakan penagihan melalui surat peringatan atas wanprestasi debitor dan dokumen pokok lengkap.

\section{Pelelangan Agunan Kredit Langsung dengan Kurator Lelang}

Eksekusi atau lelang jaminan dapat langsung dengan kantor lelang tanpa melalui Pengadilan Negeri dan ațau BUPLN, dengan tujuan: Pertama, Kreditor mendapat pelunasan seluruh dan atau sebagian kewajiban debitor dengan pembayaran tunai dari penjualan jaminan debitor. Kedua, Kreditor terhindar dari tuntutan debitor atas penjualan jaminan kreditor. Ketiga, Kreditor mendapatkan fresh money. 
Persyaratan pelelangan agunan kredit oleh kurator lelang adalah: Pertama, Jaminan kredit telah dilkat dengan sempurna atau hak tanggungan, artinya telah dipasang hak tanggungan (APHT) dan telah terbit Sertifikat Hak Tanggungan (SHT). Kedua, Dalam APHT harus dimuat suatu janji menjual atas kekuasaan sendiri (beding van eigen matige verkoop).

Kriteria penagihan utang melalui pelelangan agunan kredit oleh kurator lelang adalah debitor tidak kooperatif, prospek usaha debitor tidak baik, dan kualitas kolektibilitas kredit golongan loss (macet).

\section{Upaya Hukum terhadap Jaminan Pribadi (Borgtocht)}

Para penjamin atau penjamin yang telah mengikatkan diri kepada bank yang secara tegas termuat dalam akta borgtocht termasuk telah melepaskan hak-hak istimewanya berkewajiban membayar seluruh utang debitor manakala. debitur cidera janji. Tujuannya adalah agar kreditor mendapat pelunasan seluruh dan atau sebagian kewajiban debitor dengan pembayaran tunai dari penjamin atau penanggung utang; dan kreditor mendapat fresh money.

Kriteria dilaksanakannya kebijakan ini adalah debitor tidak kooperatif, prospek usaha debitor tidak baik, kualitas kolektibilitas kreditnya macet. Sedangkan persyaratan yang harus dipenuhi meliputi: Penjamin atau penanggung utang telah diikat dengan sempurna, artinya telah dipasang akta borgtocht, dan dapat diketahui secara pasti kekayaan penjamin atau penanggung utang.

\section{Kepailitan}

Dalam hal debitor mempunyai utang kepada kreditor lain selain di bank dan utang tersebut jatuh tempo dan dapat ditagih, maka dapat ditempuh upaya melalui permohonan penyataan pailit ke Pengadilan Niaga. Tujuan dari kebijakan ini adalah untuk mencegah sitaan dan eksekusi oleh seorang kreditor atau lebih secara perseorangan atau untuk menghentikan sitaan atau eksekusi tersebut. Sitaan atau eksekusi (boedel) dibagi-bagikan secara adil di antara para kreditor, dengan mengingat hak-hak para pemegang hak istimewa yaitu gadai dan hak tanggungan.

Kriteria kepailitan bagi debitor adalah: Pertama, Prioritas pertama adalah manajemen debitor yang mempunyai itikad baik dan jaminan kredit telah diikat sempurna. Kedua, Debitor dengan itikad baik, jaminan kredit belum diikat sempurna, namun mencukupi. Ketiga, Debitor dengan itikad baik, memiliki aset yang tidak dijaminkan ke kreditor atau bank dijaminkan ke kreditor lain. Keempat, Kualitas kolektibilitas kredit adalah macet.

Apabila yang dipilih perusahaan properti adalah mekanisme kepailitan, maka akibat hukum yang akan muncul adalah: Pertama, Perusahaan akan kehilangan hak untuk berbuat bebas terhadap kekayaan yang termasuk dalam kepailitan terhitung mulai dari pernyataan pailit. Kedua, Segala perikatan yang terbit sesudah pernyataan pailit tidak dapat dibayar dari harga pailit; sehingga para pihak harus berhati-hati dalam berhubungan dengan badan usaha yang dinyatakan pailit. Ketiga, Dilakukan penjualan harta pailit dalam pelelangan, dan hasilnya digunakan untuk memenuhi tuntutan utang para kreditor. 


\section{Simpulan}

Pemerintah, khususnya Bank Tabungan Negara telah menyediakan berbagai macam restrukturisasi kredit properti dan real estate yang merupakan langkah terbaik bagi penyelesaian non performance loans. Namun demikian, penyelesaian utang dengan harus dilaksanakan dengan mempertimbangkan keberlangsungan bisnis sektor properti dan real estate. Konsekuensi dari restrukturisasi dimungkinkan adanya perubahan kedudukan dan peran kepengurusan, permodalan dan struktur utang.

Cost benefit analysis, dan prinsip keadilan bagi penyelesaian "lahan tidur" mutlak dilaksanakan dengan memperhatikan kebutuhan masyarakat secara luas. Untuk itu, jiwa enterpreneurship harus dikembangkan bagi kemandirian sektor properti dan real estate, sehingga profesionalisme pelaku usaha dapat terjamin. $\square$

\section{Daftar Pustaka}

Badrulzaman, Mariam Darus. et. al. 2001. Kompilasi Hukum Perikatan. Bandung: Citra Aditya Bakti.

Data Statistik. 31 Desember 1998.

Easterbook, $\mathrm{H}$. "The Inevitability of Law and Economics." Legal Education Review. Vol 1 No. 1 Tahun 1989.

Indroyono, Gatot. "Celah Orang Berutang". Media Indonesia. 20 September 1998.

Martin, John D. et. al. 1995. Dasar-dasar Manajemen Keuangan. Jakarta: Raja Grafindo Persada.
Media Indonesia. 20 September 1998.

Pandojo, Heindjrachman Ranu. et. al. 1982.

Pengantar Ekonomi Perusahaan. Yogyakarta: BPFE.

Panggabean, H.P. "Berbagai Masalah Yuridis yang Dihadapi Perbankan Mengamankan Pengembalian Kredit yang Disalurkannya". Varia Peradilan. No. 80 Tahun 1992.

Purnomosidi, Lukman. "Restrukturisasi Utang Sektor Real Estate menuju Pemulihan Ekonomi”. Makalah Seminar Nasional Rekapitalisasi Perbankan dan Restrukturisasi Kredit Sektor Properti. Jakarta. 25 Februari 1999.

Panangian Simanungkalit. "Rekapitulasi Perbankan dan Restrukturisasi Kredit Properti". Makalah Seminar Rekapitalisasi Perbankan Nasional. Jakarta: Intact Consuiting Indonesia. 25 Februari 1999.

Rajagukguk, Erman. Tanpa Tahun. "Analisis Ekonomi dalam Hukum Kontrak.." Makalah.

Riyanto, Bambang dalam Hidjrachman Ranupandojo et. al. 1989. Pengantar Ekonomi Perusahaan. Buku 2. Yogyakarta: BPFE. Rijanto. "Rekapitalisasi Perbankan." Makalah Seminar Nasional Rekapitalisasi Perbankan dan Restrukturisasi Kredit Properti. Jakarta: Intact Consulting Indonesia. 25 Februari 1999.

Sambutan Ketua Badan Pengawas Pasar Modal Seminar Nasional Rekapitalisasi Perbankan Nasional dan 
Restrukturisasi Kredit Sektor Properti. Jakarta: Intact Consulting Indonesia. 25 Februari 1999.

Sambuaga, Theo L. Makalah Pidato Pengarahan Seminar Nasional Prospek Investasi Properti Pasca Rekapitulasi Perbankan. Semarang: Dewan Pimpinan Daerah Real Estate Indonesia Jawa Tengah. 15 April 1999.

Sjahdeini, Sutan-Remy . "Perlindungan Debitur dan Kreditur. Dampak Undang-Undang Kepailitan terhadap Perbankan". Artikel Jurnal Hukum Bisnis. Vol. 5/1999.
Theo, Sri Indrastuti, Christian. "Debt Conversion (Kompensasi Utang)." Jurnal Penyelesaian Utang. No. 04. Jakarta. 17 Maret 1999.

Tjoekam, H. Muh. 1998. Perkreditan Bisnis Inti dan Komersial. Jakarta: Gramedia Pustaka Utama.

Watson, J. Fred \& Eugene F. Brigham. Terjemahan Alfons Srinita. 1994. Dasar-dasar Manajemen Keuangan. Jakarta: Erlangga. 